\title{
The use of cluster analysis method for the development of static load cycles of diesel engines in non road vehicles
}

\begin{abstract}
This paper presents a methodology of development of substitute cycle of loads of non road vehicle engines. The use of cluster analysis method made it possible to locate seven characteristic phases of Z8401.12 engine loads, which occur in typical conditions of tractor operation in the region of Pomorze Zachodnie. The author compared credibility breakdowns of the obtained results and stated that the obtained cycle of loads differs from the hitherto used static tests of non road vehicles.
\end{abstract}

Key words: Diesel engine, non road vehicle, cycle of loads, cluster analysis

\section{Wykorzystanie metody analizy skupień do tworzenia statycznych cykli obciążeń silników ZS pojazdów pozadrogowych}

\begin{abstract}
W artykule przedstawiono metodykę tworzenia zastępczego cyklu obciążeń silnika pojazdu pozadrogowego. Posługując się metoda analizy skupień, zlokalizowano siedem charakterystycznych faz obciążeń silnika Z8401.12, występujacych przy przeciętnych warunkach eksploatacji ciagnika na Pomorzu Zachodnim. Porównano rozkłady prawdopodobieństw uzyskanych wyników. Stwierdzono, że otrzymany cykl obciązen różni się od dotychczas stosowanych testów statycznych do badań pojazdów pozadrogowych.

Słowa kluczowe: silnik spalinowy, pojazd pozadrogowy, cykl obciązeń, analiza skupień
\end{abstract}

\section{Introduction}

Non road vehicles are used in many various sectors of economy. Among the most significant groups of the type of vehicles there are off-road vehicles, agricultural tractors and timber tractors, construction vehicles and industrial vehicles, motor watercraft, self-propelled vehicles, attached stationary units etc. Diesel engines fitted in the vehicles operate in diversified conditions of loads depending on the method of operation, which usually differs from work performed by road vehicles, i.e. transport of people or loads.

The Adjustment of the evaluation standards for average exhaust emissions and fuel consumption in Diesel engines necessitates the performance of tests on the group of vehicles in accordance with the methodology valid in the EU countries [6]. Pursuant to the methodology, engines of non road vehicles are evaluated according to a static cycle of loads (C1) combined of eight different settings of torque and engine speed within the field of engine power demand (Fig. 1).

On the basis of the above average it is possible to determine the emissions of particular exhaust components and average consumption of fuel as converted into a unit of work performed by the engine.

However, as shown by the tests performed on some types of non road vehicles such as, among others, agricultural tractors, $\mathrm{C} 1$ research test does not fully comply with the actual conditions of loads of the tractor engine and the obtained measurement results, e.g. results of average exhaust emissions, considerably diverge from the results of the operating measurements $[4,5]$.

$\mathrm{C} 1$ research cycle is deficient, which results mainly from the fact that it is common for all groups of non road vehicles, which, as a principle, makes the cycle less representative for some of the groups.

\section{Wstęp}

Pojazdy pozadrogowe (Non Road Vehicle) są wykorzystywane w wielu różnych sektorach gospodarki. Do ważniejszych grup tego rodzaju pojazdów należą: samochody terenowe, ciągniki rolnicze i leśne, pojazdy budowlane i przemysłowe, motorowe pojazdy wodne, samojezdne lub przyczepiane agregaty stacjonarne itp. Silniki spalinowe tych pojazdów pracują przy zróżnicowanych warunkach obciążeń, zależnie od sposobu eksploatacji, który jest zazwyczaj odmienny od pracy wykonywanej przez pojazdy drogowe, tj. transport osób lub ładunku.

Dostosowanie standardów oceny średnich emisji spalin oraz zużycia paliwa silników spalinowych wymusza poddanie również tej grupy pojazdów badaniom wg metodyki obowiązującej w krajach UE [6]. Zgodnie z tą metodyką, silniki pojazdów pozadrogowych ocenia się wg statycznego cyklu obciążeń (C1), który stanowi kombinację ośmiu różnych nastaw momentu i prędkości obrotowej w zakresie pola podaży mocy silnika (rys. 1).

$\mathrm{Na}$ tej podstawie ocenia się średnie emisje poszczególnych składników spalin oraz średnie zużycie paliwa w przeliczeniu na jednostkę wykonanej przez silnik pracy.

Jednak, jak wykazują badania niektórych typów pojazdów pozadrogowych, m.in. ciągników rolniczych, test badawczy $\mathrm{C} 1$ nie jest w pełni adekwatny do rzeczywistych warunków obciążeń silnika ciągnikowego, a uzyskane wyniki pomiarów, np. średnich emisji spalin, znacznie odbiegają od wyników pomiarów eksploatacyjnych $[4,5]$.

Niedoskonałość cyklu badawczego $\mathrm{C} 1$ wynika głównie stąd, że jest on wspólny dla wszystkich grup pojazdów pozadrogowych, co z założenia czyni go mało reprezentatywnym dla niektórych z tych grup. 


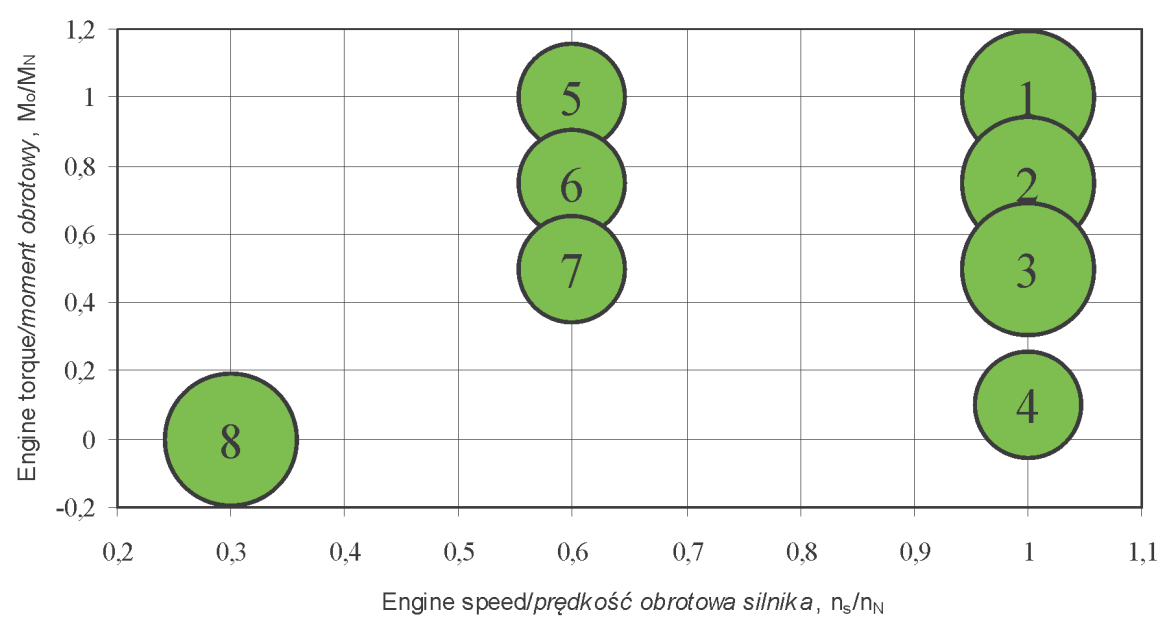

Fig. 1. 8-phase static cycle of loads $\mathrm{C} 1$ (circle areas being proportional to the share of individual phases) [6]; $\mathrm{M}_{\mathrm{o}}$ - instantaneous torque, $\mathrm{M}_{\mathrm{N}}$ - rated power torque, $\mathrm{n}_{\mathrm{s}}$ - instantaneous engine speed, $\mathrm{n}_{\mathrm{N}}-$ rated power engine speed Rys. 1. Ośmiofazowy, statyczny cykl obciążeń C1 (pola powierzchni kót proporcjonalne do udziału poszczególnych faz) [6]; $M_{o}$ - chwilowy moment obrotowy, $M_{N}$ - moment obrotowy mocy znamionowej, $n_{s}-$ chwilowa prędkość obrotowa, $n_{N}$ - prędkość obrotowa mocy znamionowej

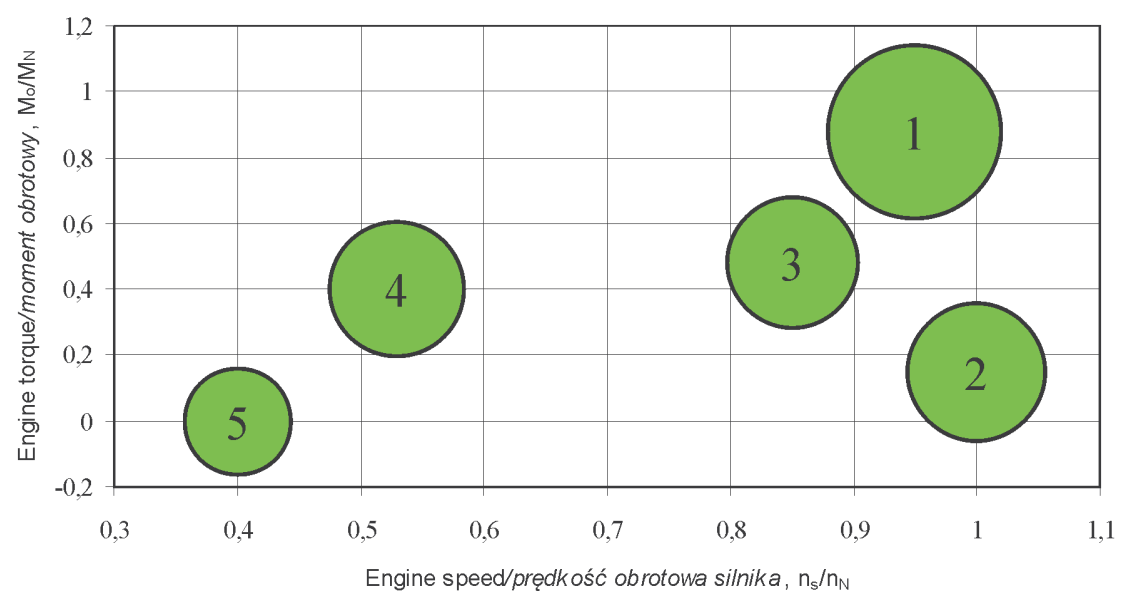

Fig. 2. P5-phase Deutz static cycle of loads (circle areas being proportional to shares of particular phases) [5]; $\mathrm{M}_{\mathrm{o}}$ - instantaneous torque, $\mathrm{M}_{\mathrm{N}}$ - rated power torque, $\mathrm{n}_{\mathrm{s}}$ - instantaneous engine speed, $\mathrm{n}_{\mathrm{N}}-$ rated power engine speed Rys. 2. Pięciofazowy, statyczny cykl obciążeń Deutza (pola powierzchni kót proporcjonalne do udziału poszczególnych faz) [5]; $M_{o}-$ chwilowy moment obrotowy, $M_{N}-$ moment obrotowy mocy znamionowej, $n_{s}-$ chwilowa prędkość obrotowa, $n_{N}$ - prędkość obrotowa mocy znamionowej
Chcąc sprostać wymaganiom, dotyczącym określenia przeciętnych warunków eksploatacji pojazdów pozadrogowych, opracowano symulacyjny test obciążeń charakterystyczny dla silników ciągników rolniczych [5]. Stworzony test badawczy (model eksploatacji) oparty jest na pięciu typowych czynnościach agrotechnicznych wykonywanych przez ciągnik rolniczy (rys. 2).

Jednak test Deutza [5], już w opinii jego autorów, nie uwzględnia pewnych, trudnych do określenia, stanów przejściowych silnika związanych z czynnościami ciągnika, takimi jak: agregatowanie sprzętu, jazda ciągnika na biegach pełzających (poniżej 3,6 km/h) lub wykorzystanie ciągnika $\mathrm{w}$ napędach stacjonarnych przez PTO (Power Take Off). Dlatego też należałoby, dla każdej z grup pojazdów pozadrogowych, stworzyć odrębny test badawczy, który spełniałby wymagania w zakresie oceny średnich emisji spalin i zużycia paliwa. W niniejszym artykule zaproponowano metodykę tworzenia zastępczego cyklu obciążeń na przykładzie ciągnika rolniczego, posługując się metodą analizy skupień zarejestrowanych obciążeń silnika Z8401.12.
In order to comply with the requirements relating to the determination of average conditions of operation of non road vehicles, a simulation test of loads characteristic of agricultural tractor engines was developed [5]. The developed research test (operation model) is based upon five typical agricultural and technical activities performed by the agricultural tractor (Fig. 2).

However Deutz test [5], even in the opinion of its authors, does not consider certain temporary conditions of the engine, which are difficult to determine and are connected with such activities of the tractor as aggregation of equipment, operation of the tractor at creeper speed (below $3.6 \mathrm{~km} / \mathrm{h}$ ) or use of tractor stationary drives through PTO (Power Take Off). Therefore for each group of non road vehicles there should

\section{Metodyka badań}

Podstawą do stworzenia symulacyjnego cyklu badawczego silników pojazdów pozadrogowych powinien być zbiór danych o stanach pracy silnika (w układzie $n_{s}-M_{o}$ ) zarejestrowany podczas eksploatacji. Aby jednak zapewnić reprezentatywność zebranego zbioru danych, należy zwrócić uwagę na następujące czynniki $[2,7]$ :

- sprawność psychomotoryczną przeciętnego operatora (kierowcy) pojazdu, ze względu na sposób sterowania silnikiem,

- statystyczne wykorzystanie pojazdu o określonym przedziale czasowym, tj. jednego roku lub sezonu, ze względu na wystarczającą liczbę zarejestrowanych danych, 
be a separate research test complying with the requirements relating to the evaluation of average exhaust emissions and fuel consumption. This article proposes the methodology of development of substitute cycle of loads on the example of an agricultural tractor and with the use of analysis of cluster of recorded Z8401.12 engine loads.

\section{Research methodology}

The development of simulation research cycle of non road vehicle engines should be based upon a collection of data on engine work conditions (in $\mathrm{n}_{\mathrm{s}}-\mathrm{M}_{\mathrm{o}}$ system) recorded during operation. However, in order to make the collected data most representative one should pay attention to the following factors $[2,7]$ :

- psychomotor efficiency of an average operator (driver) of the vehicle in terms of driving style,

- statistic use of the vehicle in a specified time interval, i.e. during one year or season, in terms of the sufficient data recorded,

- type of work performed by the vehicle, conditions of field, climate, soil etc. in terms of values of resistance taken into account in the vehicle power balance.

Taking the above factors into account it is possible to develop a representative cycle of loads by performing the following activities in a sequence:

1) selection of a vehicle for testing from a group of given type of non road vehicles,

2) recording of engine work parameters in a sufficiently long time interval,

3) tatistical depiction of engine load conditions as a function of interval duration,

4) development of a substitute and simplified cycle of loads.

For the purposes of the development of a substitute cycle of loads of an engine, the author selected Ursus 912/14 used in an agricultural farm with the area of 38 hectares, which constitutes an average farm organizational system in the region of the Zachodniopomorskie Province. The operating conditions of Z8401.12 engine were recorded with the use of TRS (Tractor Recording System) [3].

The substitute cycle of loads was performed with the use of cluster analysis method being a statistical tool for explorative analysis of data. The aim of the method is to divide objects (engine operating points) into groups, so that the degree of relationship of objects with objects belonging to the same group was possibly the greatest and the degree of relationship of other objects to objects belonging to other groups was possibly the least. For the purposes of cluster formation, the measure of distance between the objects was Euclidean space determining the real geometrical distance in $n_{s}-M_{o}$ system of coordinates. In order to divide the object into groups, the full bond method (the furthest proximity) was used, according to which the distance between clusters is determined by the largest distance between two random objects belonging to various clusters, i.e. furthest "neighbours". The method proves, if objects form naturally separated clusters. It was assumed that the method is justified also in the case of operation of a tractor engine performing
- rodzaj wykonywanej przez pojazd pracy, warunki terenowe, klimatyczne, glebowe itp., ze względu na wartości oporów uwzględnianych w bilansie mocy pojazdu.

Biorąc pod uwagę wymienione czynniki, możliwe jest stworzenie reprezentatywnego cyklu obciążeń, wykonując kolejno wybór następujące czynności:

1) wybór pojazdu do badań z populacji danej kategorii pojazdów pozadrogowych,

2) rejestracja parametrów pracy silnika w dostatecznie długim przedziale czasowym,

3) statystyczne przedstawienie stanów obciążeń silnika w funkcji czasów ich trwania,

4) stworzenie zastępczego, uproszczonego cyklu obciążeń. Do opracowania zastępczego cyklu obciążeń silnika wytypowano ciągnik Ursus 912/14 pracujący w gospodarstwie rolnym o powierzchni $38 \mathrm{~h}$, co stanowi przeciętny układ organizacyjny gospodarstwa $\mathrm{w}$ regionie zachodniopomorskim. Stany pracy silnika Z8401.12 rejestrowano za pomocą urządzenia TRS (Tractor Recording System) [3].

Zastępczy cykl obciążeń wykonano, posługując się metodą analizy skupień, która jest narzędziem statystycznym do eksploracyjnej analizy danych. Celem tej metody jest ułożenie obiektów (punktów pracy silnika) w grupy w taki sposób, aby stopień powiązania obiektów z obiektami należącymi do tej samej grupy był jak największy, a z obiektami z pozostałych grup jak najmniejszy. Przy formowaniu skupień, miarą odległości między obiektami była przestrzeń euklidesowa, wyznaczająca rzeczywistą odległość geometryczną w układzie współrzędnych $n_{\mathrm{s}}-\mathrm{M}_{\mathrm{o}}$. Jako sposób grupowania obiektów wybrano metodę pełnego wiązania (najdalszego sąsiedztwa), w której odległość między skupieniami jest zdeterminowana przez największą odległość między dwoma dowolnymi obiektami należącymi do różnych skupień, tj. najdalszymi „sąsiadami”. Metoda ta sprawdza się wtedy, gdy obiekty formują naturalnie oddzielne aglomeraty. Założono, że metoda ta jest słuszna również w sytuacji eksploatacji silnika ciągnikowego, który podczas wykonywania poszczególnych, różniących się od siebie zabiegów agrotechnicznych, rozwija charakterystyczne dla każdego zabiegu zakresy obciążeń i prędkości obrotowych. Podczas analizy metodą k-średnich przeprowadzono v-krotny sprawdzian krzyżowy, pozwalający na automatyczne wyznaczenie liczby skupień [1].

\section{Wyniki badań}

Podczas rocznej eksploatacji pojazdu uzyskano 24775 zapisów o stanie pracy silnika, co stanowiło ponad 206 godzin jego pracy. Następnie, posługując się przedstawioną metodą analizy, zlokalizowano siedem skupień w polu pracy silnika (tab. 1).

Największym udziałem, w ogólnym czasie pracy silnika, charakteryzowało się skupienie 1 . Jest ono adekwatne do obciążeń silnika ciągnikowego w transporcie i pracach z udziałem PTO, wymagających przede wszystkim wysokich prędkości obrotowych silnika w celu zapewnienia żądanej prędkości jazdy (ok. $30 \mathrm{~km} / \mathrm{h}$ ) lub znamionowych prędkości obrotowych PTO (540 obr/min lub 1000 obr/min). Charakterystyczny dla skupienia 2, najwyższy z 
particular different agricultural operations, during which it develops ranges of loads and engine speeds characteristic of each of such operations. In the course of the analysis using k-means, the author performed v-multiple cross test making it possible to determine the number of clusters in an automatic manner [1].

\section{Test results}

During the annual operation of the vehicle the author obtained 24775 records concerning condition of the engine work, which constituted 206 working hours of the engine. Next, the author located seven clusters in the engine operation field with the use of the above-presented analysis method (Tab. 1).

Cluster 1 was characterised by the largest share in the general time of engine operation. The share is commensurate uzyskanych w analizie, średni moment obrotowy silnika, świadczy o stanach pracy odpowiadających wykonywaniu ciężkich zabiegów agrotechnicznych, np. orki. Skupieniu 7 i 6 przyporządkować można pracę silnika na biegu jałowym oraz wykonywanie manewrów przez ciągnik, przy niewielkim obciążeniu silnika. Skupienia 3, 4 i 5 to typowe stany pracy silnika obciążonego oporem agregatów uprawowych i siewnych.

Podobną identyfikację obciążeń można przeprowadzić dla innych pojazdów pozadrogowych, przyporządkowując poszczególne skupienia punktów pracy konkretnym czynnościom wykonywanym przez te pojazdy w warunkach eksploatacyjnych.

W tabeli 2 przedstawiono wybrane statystyki badanych zmiennych. Odchylenia standardowe prędkości obrotowych silnika dla poszczególnych skupień nie przekraczały 200

Table 1. Cluster coordinates and their shares in the general time of Z8401.12 engine operation

Tabela 1. Wspótrzędne skupień oraz ich udziały w ogólnym czasie pracy silnika Z8401.12

\begin{tabular}{|c|c|c|c|c|}
\hline $\begin{array}{c}\text { Cluster/ } \\
\text { skupienie }\end{array}$ & $\begin{array}{c}\text { Engine speed, } \mathrm{n}[\mathrm{rpm}] / \\
\text { prędkość obrotowa silnika }\end{array}$ & $\begin{array}{c}\text { Engine torque, Mo [N·m]/ } \\
\text { moment obrotowy }\end{array}$ & $\begin{array}{c}\text { Number of cases/ } \\
\text { liczba przypadków }\end{array}$ & 4058 \\
\hline 3 & 1739.3 & 154.0 & 3241 \\
\hline 4 & 1472.5 & 70.7 & 4099 \\
\hline 7 & 582.5 & 30.7 & 16.4 \\
\hline 5 & 1106.1 & 124.5 & 2232 \\
\hline 6 & 993.7 & 51.7 & 3150 \\
\hline 1 & 2023.6 & 72.5 & 16.0 \\
\hline 2 & 1745.1 & 225.7 & 4657 \\
\hline
\end{tabular}

with the tractor engine load during transport and works using PTO, which require high engine speed in order to ensure the required driving speed (approx. $30 \mathrm{~km} / \mathrm{h}$ ) or PTO rated engine speeds (540 rpm or $1000 \mathrm{rpm}$ ). The average engine torque characteristic of cluster 2 with the highest result obtained in the analysis is evidence of conditions of work corresponding to performance of hard agricultural and technical operations such as ploughing. Clusters 7 and 6 may be assigned to the engine idle speed and manoeuvres of the tractor performed under small load of the engine. The clusters 3, 4 and 5 are characteristic of operating conditions of the engine loaded with resistance of planting and seeding cultivation units.

Similar identification of loads may be performed for other non road vehicles by assigning particular clusters of operating points to specific activities performed by the ve- obr/min, a odchylenia standardowe momentu obrotowego $30 \mathrm{~N} \cdot \mathrm{m}$.

Uzyskane rozkłady zmiennych (rys. 3 i 4) pozwalają na porównanie poszczególnych skupień pod względem prawdopodobieństwa ich wystąpienia.

Zauważyć można, że prawdopodobieństwa wystąpienia określonych prędkości obrotowych silnika w poszczególnych skupieniach (rys. 3) są ponad pięciokrotnie mniejsze w stosunku do prawdopodobieństw momentów obrotowych (rys. 4). Wynika to głównie z dokładności pomiaru tych dwóch zmiennych. Pomiar prędkości obrotowej silnika prowadzony był przy większej dokładności urządzeń (błąd ok. $1 \%$ ), a więc przy większym rozrzucie wyników pomiarów w stosunku do momentu obrotowego, który wyznaczano metodą pośrednią, z błędem ok. 5\% [3].

Table 2. Selected variables statistics in $n_{s}-M_{0}$ system

Tabela 2. Wybrane statystyki zmiennych $w$ uktadzie $n_{s}-M_{o}$

\begin{tabular}{|l|c|c|c|c|c|c|c|}
\hline Cluster/skupienie & 3 & 4 & 7 & 5 & 6 & 1 \\
\hline Min $[\mathrm{rpm}-\mathrm{N} \cdot \mathrm{m}]$ & $1412.0-104.6$ & $1228.0-19.4$ & $400.0-7.7$ & $542.0-86.7$ & $724.0-4.3$ & $1748.0-14.7$ & $836.0-189.4$ \\
\hline $\max [\mathrm{rpm}-\mathrm{N} \cdot \mathrm{m}]$ & $2300.0-190.5$ & $1752.0-110.8$ & $850.0-88.9$ & $1410.0-275.0$ & $1290.0-97.9$ & $2300.0-143.9$ & $2300.0-307.6$ \\
\hline$\overline{\mathrm{x}}[\mathrm{rpm}-\mathrm{N} \cdot \mathrm{m}]$ & $1746.2-154.4$ & $1472.3-70.4$ & $581.7-30.6$ & $1121.0-125.6$ & $988.5-52.4$ & $2023.4-72.4$ & $1742.6-226.2$ \\
\hline $\mathrm{S}[\mathrm{rpm}-\mathrm{N} \cdot \mathrm{m}]$ & $171.5-22.3$ & $136.5-22.0$ & $112.6-21.6$ & $194.4-27.8$ & $127.9-20.5$ & $118.8-22.5$ & $168.6-24.5$ \\
\hline
\end{tabular}


hicles in operating conditions.

The Table 2 presents selected statistics of the tested variables. Standard deviations of engine speeds for particular clusters did not exceed 200 rpm and standard deviations of torque did not exceed 30 $\mathrm{N} \cdot \mathrm{m}$.

The obtained variables distributions (Fig. 3 and 4) make it possible to compare particular clusters depending on credibility of their occurrence.

It may be observed that the occurrence of specified engine speeds in particular clusters (Fig. 3) is five times less credible than in the case of torque (Fig. 4). This mainly results from the accuracy of measurements of the two variables. The engine speed was measured by the equipment with greater accuracy (error of approx. $1 \%$ ) and therefore the range of measurement results was greater as compared with the torque results, which were determined with the use of an indirect method allowing for an error of approx. 5\% [3].

The credibility resulting from the obtained distributions could also be higher (more credible) for the developed test, if a greater number of clusters was assumed. However, excessive increase of the number of clusters, which, at the same time, constitute individual phases of the static cycle, would complicate and prolong the research procedure, which is relevant in the case of engine tests performed in a chassis dynamometer. Therefore it was assumed that the number of clusters in the developed load test should not exceed the

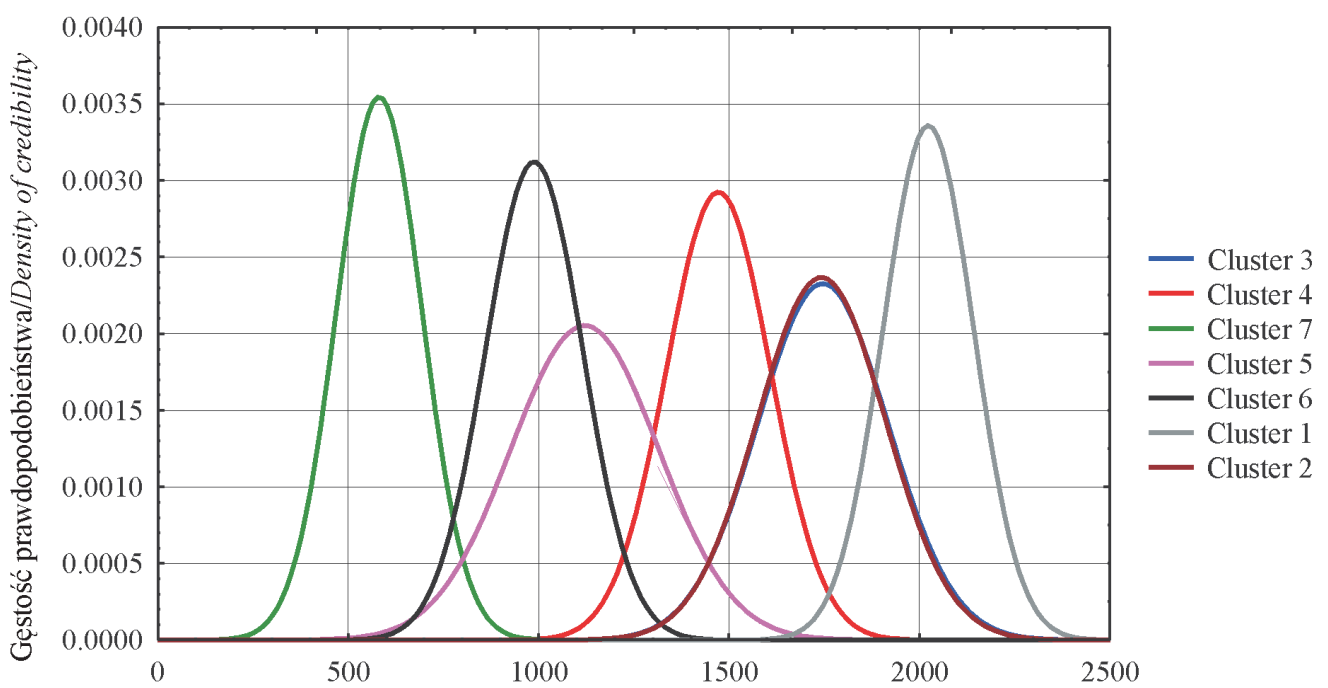

Fig. 3. Credibility distributions of Z8401.12 engine speeds for particular clusters

Rys. 3. Rozkłady prawdopodobieństw prędkości obrotowej silnika Z8401.12 dla poszczególnych skupień

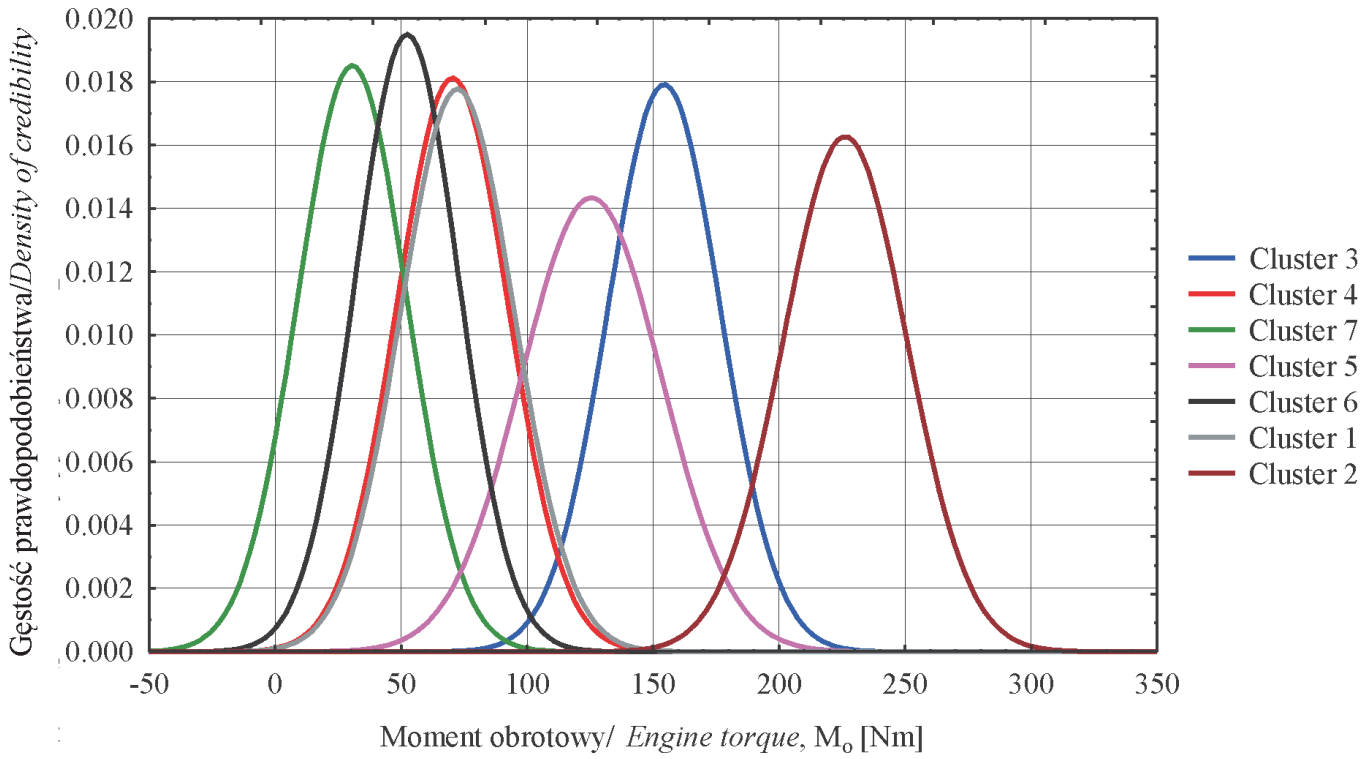

Fig. 4. Credibility distributions of Z8401.12 torque for particular clusters

Rys. 4. Rozkłady prawdopodobieństw momentu obrotowego silnika Z8401.12 dla poszczególnych skupień

Wynikające z uzyskanych rozkładów prawdopodobieństwa mogłyby być również wyższe (bardziej wiarygodne) dla tworzonego testu, gdyby przyjęto większą liczbę skupień. Jednak nadmierne zwiększenie liczby skupień, które są jednocześnie pojedynczymi fazami cyklu statycznego, komplikuje i wydłuża procedurę badawczą, co przy realizacji badań silnika na stanowisku dynamometrycznym ma istotne znaczenie. Dlatego przyjęto, że liczba skupień w tworzonym teście obciążeń nie powinna przekraczać liczby faz cyklu C1.

Na podstawie wyznaczonych współrzędnych oraz ich statystyk (tab. 1 i 2) sporządzono siedmiopunktowy rozkład 
number of phases of C1 cycle.

On the basis of the determined coordinates and their statistics (Tab. 1 and 2) the author developed a 7-point distribution of loads in a non-dimensional universal characteristics field (Fig. 5).

The cycle phases were numbered so that the engine could operate at decreasing engine speeds and decreasing loads for each of the phases during dynamometric test, which is the case of standard static test cycles.

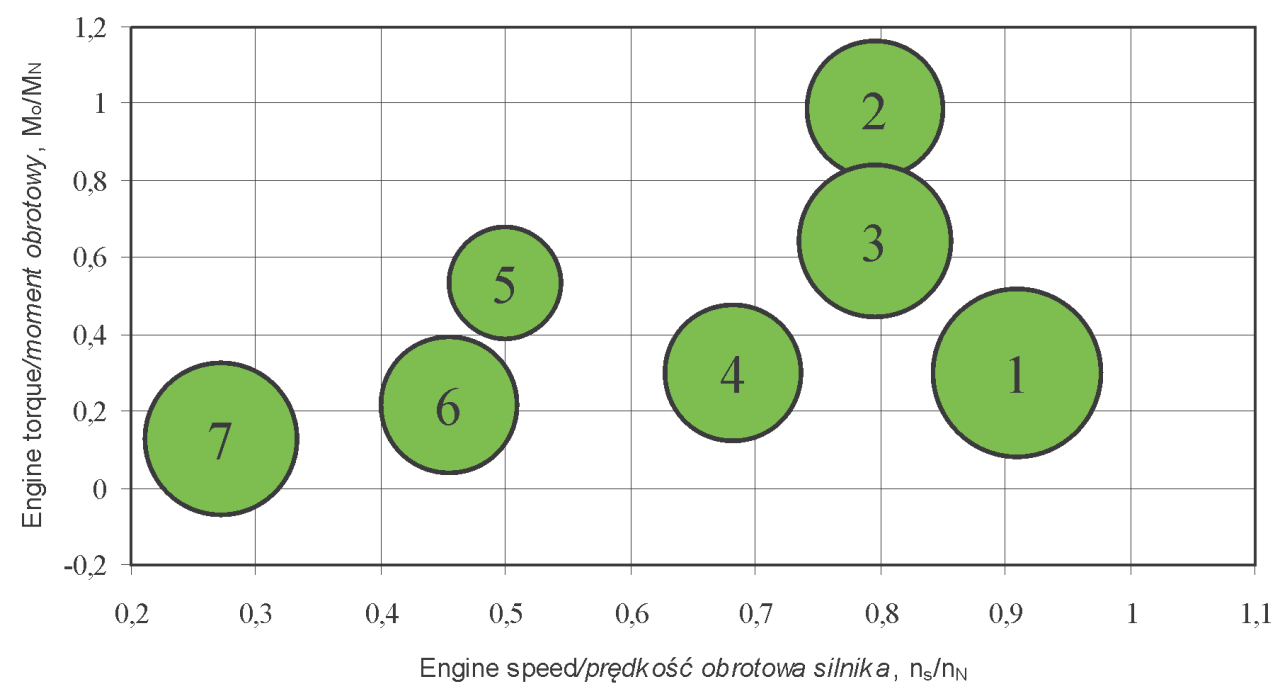

Fig. 5. 7-phase static cycle of loads (circle areas being proportional to shares of particular phases); $\mathrm{M}_{\mathrm{o}}-$ instantaneous torque, $\mathrm{M}_{\mathrm{N}}$ - rated power torque, $\mathrm{n}_{\mathrm{s}}$ - instantaneous speed, $\mathrm{n}_{\mathrm{N}}-$ rated power speed

Rys. 5. Siedmiofazowy, statyczny cykl obciażén (pola powierzchni kót proporcjonalne do udziału poszczególnych faz); $M_{o}$ - chwilowy moment obrotowy, $M_{N}$ - moment obrotowy mocy znamionowej, $n_{s}$ - chwilowa prędkość obrotowa, $n_{N}$ - prędkość obrotowa mocy znamionowej

The table 3 presents a comparison of selected test cycles of engines installed in non road vehicles. The comparison has the form of non-dimensional coordinates of engine speed, torque and weight coefficients.

As results from Table 3, the 8-phase cycle is characterised by the greatest weighted average of the engine power, i.e. $\mathrm{N}_{\mathrm{e}} / \mathrm{N}_{\text {znam }}=0.44$. In the 5-phase cycle the weighted average of the engine power has the value of 0.37 , whereas in the 7 -phase cycle it is 0.28 . Therefore, the weighted average load of the engine during the 7-phase cycle is lower by over $24 \%$ as compared to the 5 -phase cycle and by over $36 \%$ as compared to the 8-phase cycle. Therefore one should assume that such a great diversification of engine loads during chassis dynamometer tests must be reflected in the level obciążeń w polu bezwymiarowej charakterystyki uniwersalnej (rys. 5).

Fazy cyklu ponumerowano w taki sposób, aby podczas badań na stanowisku dynamometrycznym silnik pracował przy malejących prędkościach obrotowych i malejącym obciążeniu dla każdej z faz, podobnie jak ma to miejsce w standardowych, statycznych cyklach badawczych.

Porównanie wybranych cykli badawczych silników zainstalowanych w pojazdach pozadrogowych przedstawiono $\mathrm{w}$ tab. 3, w postaci bezwymiarowych współrzędnych prędkości obrotowej i momentu obrotowego oraz współczynników wagi.

Jak wynika z tabeli 3, największą średnią ważoną mocy silnika, tj. $\mathrm{N}_{\mathrm{e}} / \mathrm{N}_{\text {znam }}=0,44$, charakteryzuje się cykl ośmiofa-

Table 3. Comparison of selected static load tests for engines installed in non road vehicles

Tabela 3. Porównanie wybranych, statystycznych testów obciązeń silników pojazdów pozadrogowych

\begin{tabular}{|c|c|c|c|c|c|c|c|c|c|}
\hline \multicolumn{2}{|c|}{ Number of phase/numer fazy } & 1 & 2 & 3 & 4 & 5 & 6 & 7 & 8 \\
\hline \multirow{3}{*}{$\begin{array}{l}\text { 8-phase } \\
\text { cycle/cykl } \\
\text { 8-fazowy }\end{array}$} & $\mathrm{n}_{\mathrm{s}} / \mathrm{n}_{\mathrm{N}}$ & 1 & 1 & 1 & 1 & 0.6 & 0.6 & 0.6 & 0.3 \\
\hline & $\mathrm{M}_{\mathrm{o}} / \mathrm{M}_{\mathrm{N}}$ & 1 & 0.75 & 0.5 & 0.1 & 1 & 0.75 & 0.5 & 0 \\
\hline & $\begin{array}{c}\text { coefficient of weight/ } \\
\text { wspótczynnik wagi }\end{array}$ & 0.15 & 0.15 & 0.15 & 0.1 & 0.1 & 0.1 & 0.1 & 0.15 \\
\hline \multicolumn{2}{|c|}{ Number of phase/numer fazy } & 1 & 2 & 3 & 4 & & & & 5 \\
\hline \multirow{3}{*}{$\begin{array}{l}\text { 5-phase } \\
\text { cycle/cykl } \\
5 \text {-fazowy }\end{array}$} & $\mathrm{n}_{\mathrm{s}} / \mathrm{n}_{\mathrm{N}}$ & 0.95 & 0.85 & 0.53 & 1 & & & & 0.4 \\
\hline & $\mathrm{M}_{\mathrm{o}} / \mathrm{M}_{\mathrm{N}}$ & 0.88 & 0.48 & 0.4 & 0.15 & & & & 0 \\
\hline & $\begin{array}{c}\text { coefficient of weight/ } \\
\text { wspótczynnik wagi }\end{array}$ & 0.31 & 0.18 & 0.19 & 0.2 & & & & 0.12 \\
\hline \multicolumn{2}{|c|}{ Number of phase/numer fazy } & 1 & 2 & 3 & 4 & 5 & 6 & & 7 \\
\hline \multirow{3}{*}{$\begin{array}{l}\text { 7-phase } \\
\text { cycle/cykl } \\
\text { 7-fazowy }\end{array}$} & $\mathrm{n}_{\mathrm{s}} / \mathrm{n}_{\mathrm{N}}$ & 0.91 & 0.8 & 0.8 & 0.68 & 0.5 & 0.45 & & 0.27 \\
\hline & $\mathrm{M}_{\mathrm{o}} / \mathrm{M}_{\mathrm{N}}$ & 0.3 & 0.99 & 0.64 & 0.3 & 0.54 & 0.21 & & 0.13 \\
\hline & $\begin{array}{c}\text { coefficient of weight/ } \\
\text { wspótczynnik wagi }\end{array}$ & 0.2 & 0.13 & 0.16 & 0.13 & 0.09 & 0.13 & & 0.15 \\
\hline
\end{tabular}


of emission of exhaust toxic components and economical engine operation.

Taking it into account that one of the most significant activities aimed at a restriction of the exhaust emission is their limitation and the hitherto applied legislative solutions relating to non road vehicle Diesel engines are not acceptable for all groups of the type of vehicles, one may develop and verify static tests of Diesel engines periodically with the use of the above-presented methodology. The example of the development of the substitute cycle of loads as presented in this article may be used, among others, in certification procedures for non road vehicles.

\section{Conclusions}

1. The cluster analysis method is a useful statistic tool for the development of measurement data relating to Diesel engine loads.

2. The developed 7-phase cycle of loads reflects the most frequent conditions of Z8401.12 engine operation.

3. The 7-phase cycle of loads differs from the 5- and 8-phase cycles as regards the weighted average of the power. The weighted average of the power is higher by $24 \%$ as compared to the 5-phase cycle and $36 \%$ as compared to the 8-phase cycle.

4. The above-presented methodology of development of substitute cycles of loads may be used in other groups of engine vehicles.

Artykut recenzowany zowy. W cyklu pięciofazowym średnia ważona mocy silnika wynosi 0,37 a w cyklu siedmiofazowym 0,28 . Średnie ważone obciążenie silnika podczas cyklu siedmiofazowego jest zatem niższe o ponad 24\% w stosunku do cyklu pięciofazowego i o ponad $36 \%$ w porównaniu z cyklem ośmiofazowym. Należy zatem przypuszczać, że tak duże zróżnicowanie obciążeń silnika podczas testów dynamometrycznych musi znaleźć swoje odbicie w poziomie emisji toksycznych składników spalin oraz ekonomice pracy silnika.

Biorąc pod uwagę, że jednym z ważniejszych działań, mających na celu ograniczenie emisji związków toksycznych w spalinach jest ich limitowanie, a dotychczas stosowane rozwiązania legislacyjne, dotyczące silników spalinowych pojazdów pozadrogowych, nie są do zaakceptowania dla wszystkich grup tego typu pojazdów, można, za pomocą przedstawionej metodyki, tworzyć i okresowo weryfikować statyczne testy badawcze silników spalinowych. Przedstawiony w artykule przykład opracowania zastępczego cyklu obciążeń może być wykorzystany m.in. w procedurach homologacyjnych pojazdów pozadrogowych.

\section{Wnioski}

1. Metoda analizy skupień jest przydatnym narzędziem statystycznym do opracowywania zarejestrowanych danych pomiarowych o stanach obciążeń silnika spalinowego.

2. Stworzony, siedmiofazowy cykl obciążeń odzwierciedla najczęściej występujące w eksploatacji stany pracy silnika spalinowego Z8401.12.

3. Siedmiofazowy cykl obciążeń różni się pod względem średniej ważonej mocy od cyklu pięciofazowego i ośmiofazowego. Średnia ważona mocy jest wyższa o $24 \%$ niż w cyklu pięciofazowym i o $36 \%$ niż w cyklu ośmiofazowym.

4. Przedstawiona metodyka tworzenia zastępczych cykli obciążeń może być wykorzystana w innych grupach pojazdów silnikowych.

\section{Bibliography/Literatura}

[1] Analiza skupień. Electronic Textbook StatSoft. http://www. statsoft.pl/textbook/stathome.html.

[2] Gajdowicz M.: Bezstopniowa przekładnia cierna jako regulator pracy silnika spalinowego w trakcji samochodowej. Silniki Spalinowe 1-2, 1990.

[3] Koniuszy A., Nadolny R.: Sposób monitoringu pracy ciągnika oraz urządzenie do jego realizacji. Zgłoszenie patentowe P 381892, 2007.

[4] Lindgren M.: Engine Exhaust Gas Emissions from Non-road Mobile Machinery. Effects of transient load conditions. Doctoral thesis, Swedish University of Agricultural Sciences, Uppsala 2004.

[5] Lindgren M., Hansson P.-A.: Effects of Engine Control Strategies and Transmission Characteristics on the Exhaust Gas Emissions from an Agricultural Tractor. Biosystem Engineering 83(1), 2002.
[6] PN-EN ISO 8178-4. Silniki spalinowe tłokowe. Pomiar emisji spalin. Cykle badawcze silników o różnym zastosowaniu. 1999.

[7] Steven H.: Development of a Worldwide Harmonised Heavyduty Engine Emissions Test Cycle. Final Report, Netherlands -Germany 2001.

Mr. Adam Koniuszy, DEng. - doctor at the Chair of Basic Technology at West Pomeranian University of Technology in Szczecin.

Dr inż. Adam Koniuszy - adiunkt w Zakładzie Podstaw Techniki Zachodniopomorskiego Uniwersytetu Technologicznego w Szczecinie.

e-mail: adam.koniuszy@agro.ar.szczecin.pl 